\title{
Effects of Tested Pack Containing Plant Extracts on Elasticity and Size of Women's Breasts
}

Yea Hun Choi', Min-Kyung Park', Yong Gyun Kim¹, Sang Mong Lee', Hong Joo Son', Hyean Cheal Park', Sun Tae Kim², In Soo Choi ${ }^{2}$ and Keun Ki Kim*

${ }^{1}$ Department of Life Science \& Environmental Biochemistry, Pusan National University, Miryang 627-706, Korea

${ }^{2}$ Department of Plant Bioscience, Pusan National University, Miryang 627-706, Korea

Received February 15, 2012 /Revised March 9, 2012 /Accepted March 14, 2012

In this study, we purified the extracts from the seeds and the roots of various plant species, including $Q$. acutissima, $C$. lanceolata, $P$. mirifica, $P$. bambusoides, and $S$. repens, and then investigated the effects of these extracts on cell growth and fat accumulation in adipocytes. We found that the extracts purified from $Q$. acutissima, $C$. lanceolata, $P$. mirifica, $P$. bambusoides, and $S$. repens more effectively increased the cell growth, as well as promoting the fat accumulation in adipocytes to a greater extent, than other extracts in vitro. Therefore, we made breast packs containing these effective extracts, and then investigated whether they were effective in enhancing the elasticity and volume of women's breasts. The measurements of breast elasticity and size revealed that the breast packs efficiently increased the elasticity and size of women's breasts. Furthermore, evaluation of the questionnaires related to usage of the breast packs indicated great satisfaction in terms of the lift, firmness, and elasticity of breasts. In conclusion, extracts purified from $Q$. acutissima, C. lanceolata, $P$. mirifica, $P$. bambusoides, and $S$. repens leading to cell growth and fat accumulation in adipocytes can effectively contribute to improving the elasticity and size of women's breasts.

Key words : Plant extract, phytoestrogen, breast volume, elasticity, 3T3-L1

\section{서 론}

최근에 여성들의 경제적 활동과 사회활동이 급속하게 증가 함으로써 대인관계 폭이 넓어지고 다양해졌다. 여성들이 자신 만의 이미지를 표현할 기회가 많아지게 되면서 외모에 대한 관심과 이미지관리 등 자신만의 개성 표출을 위하여 시간과 경제적인 투자를 다양하고 적극적으로 하고 있다[11]. 특히, 여성의 가슴은 보다 미적인 면이 강조되어 풍만하고 봉긋한 모양의 가슴을 이상적이라고 생각하는 경향이 많아졌다[4]. 이 에 이상형에 맞지 않는 가슴을 가진 여성들은 불만족하게 되 고, 내외적인 자존감을 위해서라도 본인이 추구하는 신체이미 지에 맞는 이상적인 가슴에 가까워지기 위해서 가슴성형을 고려하는 경우가 많다[19]. 하지만 가슴성형 중 가장 효과적이 고 만족도가 높은 것으로 알려진 가슴확대술은 실제로 불만의 요소가 가장 많은 성형이기도 하다. 이는 보형물 손상에 대한 불안 요인과 안전성에 대한 논란이 끊임없이 제기되고 합병증 이 생기거나 위험 요소에 비해 만족스럽지 못한 요인들이 다 양하게 작용하고 있기 때문이다[14]. 이러한 문제들로 인해 현 재 수술 없이 보다 안전하고 아름다운 가슴을 만들 수 있도록 유선조직을 활성화시켜 가슴 크기의 향상과 탄력증진의 목적

*Corresponding author Tel : +82-55-350-5543, Fax : +82-55-350-5549

E-mail : kkkim@pusan.ac.kr
으로 여성호르몬과 상관성이 있는 식물추출물 원료를 이용한 향장품의 개발연구가 늘어나고 있다.

여성의 가슴은 모유를 분비하는 유선을 포함하고 있으며, 여성 특유의 관능미를 나타내는 부위로서 유방체와 유두로 구분되는데, 유방체는 피부의 일부가 국소적으로 두터워진 곳 으로 피하지방이 많이 축적되어 있다. 가슴의 구조와 구성의 변화에는 여성의 성장에 따라 분비되는 호르몬에 관계가 있다 [17]. 여성호르몬은 사춘기로부터 성인기에 걸쳐 분비되고 많 으면 많을수록 지방이 형성되기 쉽고 가슴도 풍만해진다[7]. 이는 에스트로겐에 의해 나타나는 신체변화로서 인위적으로 생성시켜 체형변화를 유도하는 것은 어렵다[18]. 따라서 에스 트로겐과 동일한 효과가 있는 성분을 신체에 공급함으로써 이를 해결 할 수 있는데, 이는 체내에서 호르몬과 같은 작용을 하여 유선을 발달시키므로 가슴을 확대시킬 수 있다[22].

Phytoestrogen은 식물에서 유래된 에스트로겐 호르몬으로 서 구조적으로 체내에서 분비되는 estradiol과 유사하며, 이를 함유한 식품과 추출물들을 폐경기 증상의 치료에 복용한 결 과, 유방암 및 자궁암의 빈도를 낮추고 골다공증 및 심혈관계 질환의 예방효과가 있었다[6,8,15,16]. Phytoestrogen을 복용 한 결과 폐경기 전 여성들의 가슴크기를 증가시키며, 이는 유 선의 수가 증가되고 이를 구성하는 세포의 수가 증가하는 것 으로 나타났다[5]. Phytoestrogen은 일반 식물에 광범위하게 함유된 화합물들로서 특히, 대두, 칡이나 알파파[3], 푸에라리 
아[1,2] 등의 콩과 식물에 다량 함유되어 있다. Phytoestrogen 의 일종인 genistein을 생후 50 일 이전의 쥐에 투여한 결과 유선의 분화를 촉진시켜 성숙시키고[13], isoflavone formononetin을 쥐에게 투여한 결과 유선조직의 증대를 가져왔 다[23]. Phytoestrogen을 피부노화가 빠른 갱년기 여성에게 적 용했을 때 피부노화가 지연되었으며, 6 개월간의 임상실험에 서는 피부탄력을 되찾았고, 주름의 $60 \%$ 가 개선되는 생리학적 인 활성이 나타났다[21]. 푸에라리아를 함유한 화장품을 피부 에 적용하였을 때, 피부탄력과 보습에 효과가 나타났다[10]. 에스트로겐이 섬유아세포를 자극하여 콜라겐과 히알루론산 합성을 촉진시키며, 콜라겐 대사를 관여하여 기저세포 증식효 과에도 영향을 주는 것으로 알려져 있다[20]. 현재 푸에라리아, 알파파 등의 phytoestrogen을 이용한 크림형태의 화장품 개발 은 활발하게 이루어지고 있지만, 가슴확대를 위한 천연 팩에 대한 연구는 아직 이루어지지 않고 있다.

따라서 본 연구에서는 콩과식물을 비롯한 몇 종류의 식물체 로부터 phytoestrogen을 함유하는 추출물을 얻고, 지방세포에 처리하여 지방세포의 분화와 지방축적에 대한 활성을 조사하 였으며, 활성이 나타난 추출물들을 첨가하여 팩을 제조하고, 가슴크기변화에 미치는 영향을 조사하였다.

\section{재료 및 방법}

\section{식물체 및 물질추출}

지방세포의 분화와 지방의 축적을 확인하기 위하여 사용된 식물은 검정콩(Glycine max.(L.) Merrill), 더덕(Codonopsis lanceolata (Siebold \& Zucc.) Trautv.), 도토리(Quercus acutissima Carr.), 밤(Castanea crenata Sieb. et Zucc.), 질경이(Plantago asiatica L.), 차전자(Psyllium, Plantago asiatica L. seed), 레드클로 버(Trifolium pratense L.), 지모(Anemarrhena asphodeloides Bunge), 왕대(Phyllostachus bambusoides Siebold et Zucc.), 소나 무(Pinus densiflora S. et Z.), 푸에라리아(Pueraria mirifica), 톱야 자(Serenoa repens) 등 12종을 구입하여 물질추출에 사용하였 다. 각 식물체는 세절하고 음건한 후 $\mathrm{H}_{2} \mathrm{O}$, ethanol, ethyl acetate 순으로 순차적 용매추출을 실시하였다. 사용한 ethanol과 ethyl acetate는 Fisher (Scientific Korea Ltd.)사의 제품을 사용 하였다. 식물체를 건조시킨 후 $20 \mathrm{~g}$ 씩 취하고, 물을 $200 \mathrm{ml}$ 가하여 $100^{\circ} \mathrm{C}$ 에서 4 시간 환류추출하여 $20 ~ 700 \mathrm{mg}$ 의 추출물 을 얻었다. 열수추출 후 식물체는 건조시킨 다음, ethanol 100 $\mathrm{ml}$ 씩 가하여 상온에서 $200 \mathrm{rpm}$ 으로 진탕 추출하여 $5 \sim 80 \mathrm{mg}$ 의 추출물을 얻었으며, ethyl acetate추출은 ethanol 추출과 같 은 방법을 사용하여 1 20 mg의 추출물을 얻었다. 열수추출물 은 동결건조하고, 용매추출물은 감압 농축하여 추출물을 제조 하였다. 세포실험에 사용할 시료는 DMSO (Dimethyl sulfoxide, Sigma-Aldrich, Molecular biology grade)를 이용하여 $10 \mathrm{mg} / \mathrm{ml}$ 로 녹여 stock solution을 만든 후, 적정 농도로 희석
하여 사용하였다.

\section{세포배양}

실험에 사용한 3T3-L1 세포는 KCLB (Korea Cell Line Bank)에서 구입하여, $\mathrm{CO}_{2}$ incubator $\left(37^{\circ} \mathrm{C}, 5 \% \mathrm{CO}_{2}\right)$ 에서 $10 \%$ BS (Bovine Serum, Gibco, USA), 1\% PS (Penicillin and streptomycin, ThermoFisher, USA)가 포함된 DMEM (Dulbecco's Modified Eagle Medium, ThermoFisher, USA)를 사용하여 배 양하였다. 3 4일 간격으로 계대배양을 시켜가며 실험에 사용 하였다.

\section{지방축적과 세포성장}

계대배양으로 preadipocyte 상태인 3T3-L1을 이용하여 24 well plate에 동일한 수 $\left(2 \times 10^{4}\right)$ 로 cell을 seeding하였다. 3T3-L1 cello이 well 밑바닥을 덮을 정도로 배양을 한 후, 분화유도 물질 인 $0.25 \mu \mathrm{M}$ dexamethasone (DEX), $0.5 \mathrm{mM}$ methylisobutylxanthine (MIX)과 $10 \mu \mathrm{g} / \mathrm{ml}$ Insulin 을 첨가한 배양액으 로 4일간 배양하여 분화를 유도하였으며, DEX, MIX, insulin 은 Sigma-Aldrich (St. Louis, MO. USA)에서 구입하여 사용하 였다. 유도된 세포에 지방축적 효과를 조사하기 위하여 각 식 물추출물을 $25 \mu \mathrm{g} / \mathrm{ml}$ 농도로 분화유도 배지에 첨가하여 배양 하였으며, 식물추출물은 배양액을 교환할 때 2 일 간격으로 3 회 처리하였다. 10 일간 배양 후 배양액을 제거하고 $\mathrm{PBS}$ 로 세 척, $10 \%$ formalin으로 고정시킨 후 Oil Red O (Sigma-Aldrich (St. Louis, MO. USA))를 처리하여 염색하였다. 염색 후 도립 현미경을 이용하여 지방의 생성과 축척을 관찰하였고, 염색된 지방들을 isopropanol에 녹여 96 well plate에 옮긴 후 $490 \mathrm{~nm}$ 에서 흡광도를 측정하여 지방의 량을 측정하였다. 식물추출물 을 3회 처리한 이후 well에 Trypsin/EDTA (Sigma-Aldrich (St. Louis, MO. USA))를 처리하여 세포를 분리하고, trypan blue를 처리하고 세포현탁액을 만든 다음 hemocytometer를 이용하여 세포 수를 측정하였다.

\section{팩 제조}

가슴부착용 팩은 3T3-L1 세포실험에서 지방합성 활성을 나 타내는 Q. acutissima, C. lanceolata, $P$. mirifica, $P$. bambusoides, S. repens의 각 추출물을 $0.6 \%$ 씩 첨가하여 추출물을 중량의 $3 \%$ 되게 첨가하였으며, 팩은 겔타입으로 (주) 아토즈바이오에 서 제조하였다. 팩 제조에 첨가한 주요성분은 Table 1에 나타 냈다.

\section{임상실험}

식물추출물을 함유한 팩을 부착하여 가슴의 크기변화를 조 사한 시험은 B컵 이하인 23 41세(평균연령 30.6 \pm 6.3 세)의 건강 한 여성 피험자 15 명을 대상으로 하여, 피험자별 생리주기와 결혼 유무, 피부 타입(Table 2)을 조사하였다. 병력이 없는 피 
Table 1. The experimental formulation of the gel pack containing plant extract

\begin{tabular}{clll}
\hline No. & Ingredient & No & Ingredient \\
\hline 1 & water & 10 & adenosine \\
2 & glycerin & 11 & B-glucan \\
3 & butylene glycol & 12 & gelatine \\
4 & xanthan gum & 13 & PEG-10 hydrogenated castor oil \\
5 & agar & 14 & sodium acetylated hyaluronate \\
6 & collagen & 15 & phenoxyethanol \\
7 & carrageenan & 16 & disodium EDTA \\
8 & hyaluronic acid & 17 & plant extracts \\
9 & albutin & & \\
\hline
\end{tabular}

Table 2. Information of subjects $(n=15)$

\begin{tabular}{|c|c|c|c|}
\hline Item & Classification & Frequency (n) & Percentage $(\%)$ \\
\hline \multirow{3}{*}{ Menstrual cycle } & Beginning & 4 & 26.67 \\
\hline & Middle & 6 & 40.00 \\
\hline & End & 5 & 33.33 \\
\hline \multirow{2}{*}{ Marriage } & Yes & 12 & 80.00 \\
\hline & No & 3 & 20.00 \\
\hline \multirow{4}{*}{ Skin type } & Dry & 4 & 26.67 \\
\hline & Normal & 9 & 60.00 \\
\hline & Oily & 1 & 6.67 \\
\hline & Dry and Oily & 1 & 6.67 \\
\hline \multirow{3}{*}{ Skin elasticity } & Flexible & 1 & 6.67 \\
\hline & Normal & 12 & 80.00 \\
\hline & Not-Flexible & 2 & 13.33 \\
\hline \multirow{2}{*}{ Stinging } & Yes & 0 & 0.00 \\
\hline & No & 15 & 100.00 \\
\hline \multirow{2}{*}{ Adverse reaction } & Yes & 0 & 0.00 \\
\hline & No & 15 & 100.00 \\
\hline
\end{tabular}

부로 제외기준 및 선정기준에 맞는 여성으로, 6개월 동안 생리 주기가 일정한 사람을 기준으로 실험하였다.

시험기간 동안 생리주기로 인하여 가슴 크기 변화에 대한 영향을 최소화하기 위해 생리가 끝난 시점에서 실험을 시작하 였다. 샤워 후 5 일간 1 일 1 회(저녁) 식물추출물이 함유된 천연 팩을 12 시간 착용 후 제거하도록 하였고, 그 이후 천연 팩의 효능이 유지되는 기간을 조사하였다.

피험자에 의한 설문평가는 효능과 사용성에 관한 설문평가 로 각 평가시점에서 1 5점 척도(1, 전혀 그렇지 않다; 2 , 약간 그런 편이다; 3 , 변화 없다; 4 , 그런 편이다; 5 , 매우 그런 편이 다)로 피험자를 대상으로 실시하여 평가하였다.

모든 데이터의 통계적 유의성은 SPSS Package Program을 이용하여 분석하였고, 증감률은 다음과 같은 계산식에 의해 산출하였다.

증감률 $(\%)=\frac{(\text { 제품사용 후 측정값-제품사용 전 측정 값 })}{\text { 제품 사용 전 측정값 }} \times 100$

\section{가슴둘레와 탄력 측정}

천연팩 사용 전후의 가슴둘레 측정은 측정용 자를 이용하여 각 평가 시점마다 각각의 둘레를 측정하였으며, 가슴탄력 측 정은 피부 점탄성 측정 장치인 Cutometer ${ }^{\circledR} \mathrm{MPA} 580$ (CK electronic $\mathrm{GMbH}, \mathrm{Koln}, \mathrm{Germany)}$ 를 사용하였다. 부착 1일 후부터 21일까지 각 평가 시점마다 좌측 가슴의 유두 바깥 측면의 탄력을 측정한 후, 파라미터 중 R2 (gross elasticity) 및 R7 (biologic elasticity) 값을 취하여 분석하였다(Fig. 1).

\section{가슴 볼륨 측정}

피험자의 가슴 볼륨 측정은 3 차원 이미지 촬영장치인 PRIMOS $^{\circledR}$ Body 7.0 (GFMesstechnik GmbH, Berlin, Germany)을 이용하여 각 평가시점에서 가슴을 촬영한 후 볼 륨을 분석하였다(Fig. 2). 천연 팩 부착 전과 부착 후 1 일, 3 일, 5 일 그리고 부착하지 않고 21일 후에 피험자들을 대상으로 PRIMOS $^{\circledR}$ Body 7.0 전용 software를 사용하여 평가하였다. 측정 부위의 동일성을 유지하기 위하여 이미지 overlay 기능 


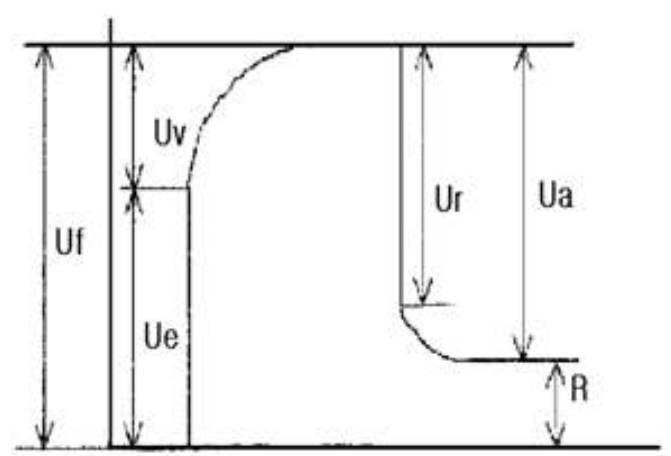

Ue: immediate distension

Uv: delayed distension

$\mathrm{U}$ : final distension

Ur: immediate retraction

$\mathrm{R}$ : resilient distension

R2 (Ua/Uf: gross elasticity)

R7 (Ur/Uf: biologic elasticity)

Uv/ue: the ratio of viscoelastic to elastic distension

$\mathrm{Ur} / \mathrm{Ue}$ : elastic ratio after the first traction

Fig. 1. Define of elasticity parameter.

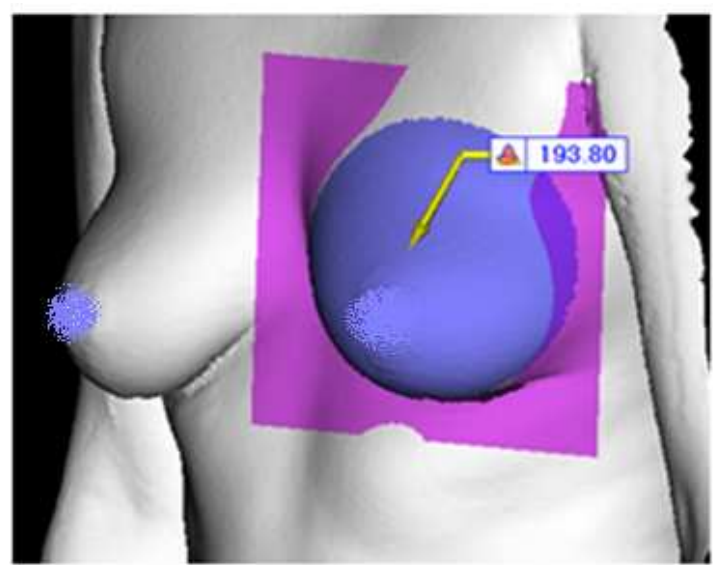

Fig. 2. Analysis image of breast volume using PRIMOS $^{\circledR}$ Body 7.0.

\section{을 사용하였다.}

\section{피부안전성 평가}

피부 안전성 평가에 참가한 피험자는 건강하고 병력이 없는 피부를 가진 한국 여성 15 명을 대상으로 5 일간 사용하게 하였 다. 각 평가시점에서 관찰 및 문진을 통해 주관적 피부 자극감 과 객관적 피부 자극을 평가하였다. 시험 도중, 다음과 같은 이상반응 및 그 밖의 이유로 탈락한 피험자는 없었으며 최종 피험자 수는 15 명이다. 피험자 방문 시 마다 객관적 자극감으 로 홍반, 부종, 각질박리, 구진 등을 관찰하였고, 주관적 자극 감으로 가려움, 찌르는 느낌, 근질거림, 열이 나는 느낌, 따가 움, 뺏뺏함, 당김 등을 관찰하였다. 방문한 날이 아니더라도 시험에 더 이상 참가 할 수 없게 되는 경우는 시험을 포기하도 록 하였다.

\section{통계처리}

지방축적과 세포성장실험은 3회 이상 반복하였고, 측정결 과는 평균표준편차로 표시하였으며 Sigma plot를 이용하 여 Student $t$-test를 실시하였다. 임상실험결과의 통계처리는
SPSS Package Program 11.5의 paired $t$-test 방법을 이용하 여 분석하였으며, $p$ 값이 0.05 미만일 때 유의한 것으로 평가 하였다.

\section{결과 및 고찰}

\section{세포성장과 지방 축적}

3T3-L1 세포의 분화를 유도한 후 지방합성과 축적활성을 확인하기 위하여 G. $\max$ 외 11 종 식물체의 $\mathrm{H}_{2} \mathrm{O}$ 추출물과 ethanol 추출물을 $25 \mu \mathrm{g} / \mathrm{ml}$ 농도로 처리하여 관찰하였다. 식 물체 추출물을 용해시키기 위하여 사용한 DMSO는 3T3-L1 세포에 아무런 영향을 미치지 않았으며, control에는 DMSO만 을 첨가하였다. 식물추출물을 마지막 처리한 후 2 일째부터 처 리구의 세포 밀집도에 변화가 나타났으며, control에 비해 $Q$. acutissima, C. lanceolata, P. mirifica, P. bambusaides, S. repens의 추출물을 처리한 well에서 세포의 밀집도가 높아지는 것을 확 인할 수 있었고, S. repens, P. mirifica, C. lanceolata 순으로 세포 의 성장과 밀집도가 증가했다(Fig. 3). 식물추출물 마지막 처리 후 3일이 지나면 lipid droplet 현상이 나타나기 시작하여 4일 후에는 lipid droplet이 well 곳곳에 군집현상으로 관찰되어졌 다. 처리 6일째 oil-red O 염색을 실시한 결과 control과 비교했 을 때 Q. acutissima, C. lanceolata, P. bambusoides의 ethanol 추 출물과 P. mirifica와 S. repens의 $\mathrm{H}_{2} \mathrm{O}$ 추출물을 처리한 well에 서 붉은 lipid droplet이 많이 형성되어진 것을 확인 할 수 있었 으며, 특히 P. bambusoides ethanol 추출물과 S. repens $\mathrm{H}_{2} \mathrm{O}$ 추 출물을 처리한 well에서 가장 많은 lipid droplet을 확인 할 수 있었다. 조릿대 잎 추출물을 이용한 지방세포의 지방축적 실험 결과, $70 \%$ ethanol 추출물과 열수추출물을 25 100 $\mu$ $\mathrm{g} / \mathrm{ml}$ 농도로 처리한 결과 농도의존적으로 지방세포 내 지방 축적을 증가시켰으나, 200 250 $\mu \mathrm{g} / \mathrm{ml}$ 의 농도에서는 지방축 적을 저해한다는 보고가 있었다[12]. 본 연구에서도 대나무잎 추출물 $25 \mathrm{\mu g} / \mathrm{ml}$ 농도로 처리했을 때 지방축적이 증가하는 결과와 일치하였다. 대나무 잎 추출물에는 풍부한 flavonoid 

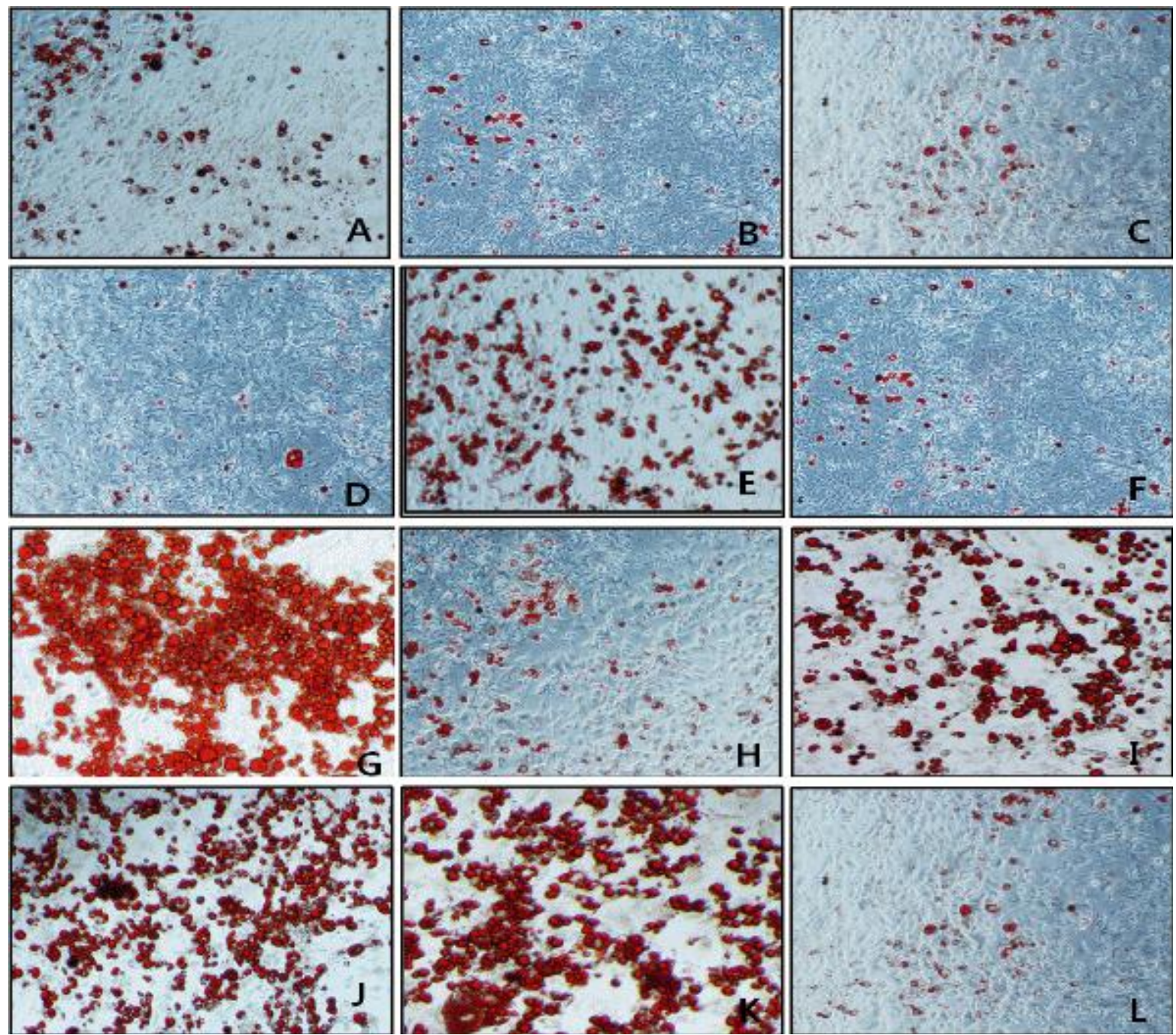

Fig. 3. Morphology of Oil Red O strained adipocyte 3T3-L1. (A) Control, (B) DMSO, (C) G. max H2O ext., (D) C. crenata EtOH ext., (E) Q. acutissima $\mathrm{E} \mathrm{OH}$ ext., (F) T. pratense $\mathrm{H} 2 \mathrm{O}$ ext., (G) S. repens $\mathrm{H} 2 \mathrm{O}$ ext., $(\mathrm{H}) A$. asphodeloides $\mathrm{H} 2 \mathrm{O}$ ext., (I) $P$. mirifica $\mathrm{H} 2 \mathrm{O}$ ext., (J) C. lanceolata $\mathrm{EtOH}$ ext., (K) P. bambusoides $\mathrm{EtOH}$ ext., (L) P. asiatica EtOH ext..

가 함유되어있어 항산화활성[25]과 피부세포 활성화에 의한 탄력증진이 가슴의 크기 변화에 영향을 미치는 것으로 추측된 다. S. repens $\mathrm{H}_{2} \mathrm{O}$ 추출물의 지방축적활성이 control보다 $190 \%$ 높았고 가장 높게 나타났는데, control보다 $190 \%$ 높았고(Fig. 3), 세포성장도 $125 \%$ 높게 나타났다(Fig. 4). S. repens 는 서인 도제도나 미국 동남부에 자생하는 식물로 원료확보에 어려움 이 있으나, 현재 전립선관련 질환 치료보조제로 개발되어 사 용되고 있어, 안전성과 산업화에 문제가 없을 것으로 사료된 다. P. mirifica의 isoflavone이 estrogen 분비를 촉진하여 피부 의 탄력과 가슴확대에 효과가 있다는 보고가 있으며[24], 본 실험에서도 P. mirifica의 $\mathrm{H}_{2} \mathrm{O}$ 추출물을 $25 \mu \mathrm{g} / \mathrm{ml}$ 농도로 처리 하였을 때 세포성장과 지방축적이 대조구에 비해 세포성장과 지방축적이 각각 $130 \%$ 와 $140 \%$ 증가하였다(Fig. 3, 4). C. lanceolata ethanol 추출물을 처리한 곳에서 3T3-L1의 세포성장률
이 control보다 $150 \%$ 높았으며, 지방축적은 $140 \%$ 높게 나타났 다(Fig. 3, 4). C. lanceolata는 식품으로서도 많이 이용할 뿐만 아니라 가양주로 담아서도 많이 복용을 해왔기 때문에 이용에 는 문제가 없을 것이다. 가슴의 크기를 증대시키는 활성이 있 다는 P. mirifica 보다 C. lanceolata ethanol 추출물이 세포성장 과 지방축적을 각각 $10 \%$ 높게 나타났다. $G . m a x \mathrm{H}_{2} \mathrm{O}$ 추출물과 A. asphodeloides $\mathrm{H}_{2} \mathrm{O}$ 추출물은 세포의 생육과 지질의 합성을 모두 억제하였다. G. max와 A. asphodeloides 는 식품과 한약재 로 사용되어지고 있고, 추출물이 지방세포의 성장과 지질합성 을 억제하므로 비만억제를 위한 목적으로 다양하게 활용할 수 있을 것이다. C. crenata ethanol 추출물, T. pratense $\mathrm{H}_{2} \mathrm{O}$ 추출물 및 $P$. asiatica ethanol 추출물은 세포의 생육에는 영향을 미치지 않고 지질합성만을 억제하는 현상이 나타났다. 식물 종에 따라 서 추출되는 phytoestrogen은 지방세포에 대한 분화와 지방축 


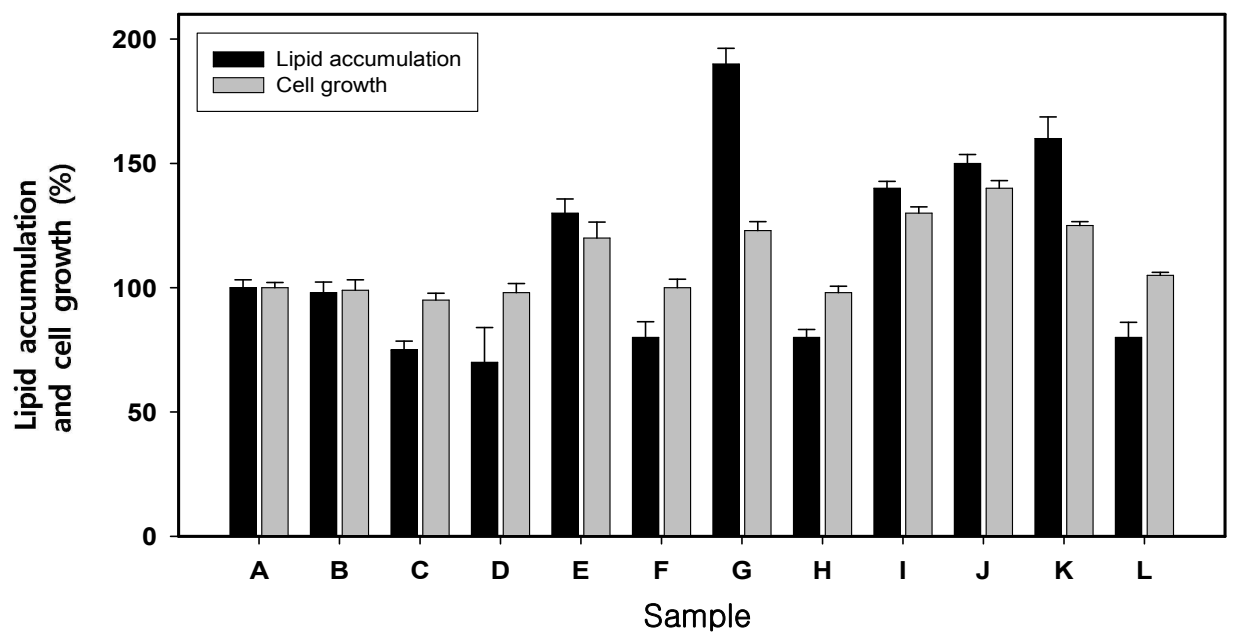

Fig. 4. Effect of plant extracts on lipid accumulation and cell growth in adipocyte 3T3-L1. Control, (B) DMSO, (C) G. max $\mathrm{H}_{2} \mathrm{O}$ ext., (D) C. crenata EtOH ext., (E) Q. acutissima EtOH ext., (F) T. pratense $\mathrm{H}_{2} \mathrm{O}$ ext., (G) S. repens $\mathrm{H}_{2} \mathrm{O}$ ext., (H) A asphodeloides $\mathrm{H}_{2} \mathrm{O}$ ext., (I) P. mirifica $\mathrm{H}_{2} \mathrm{O}$ ext., (J) C. lanceolata EtOH ext., (K) P. bambusoides EtOH ext., (L) P. asiatica EtOH ext.
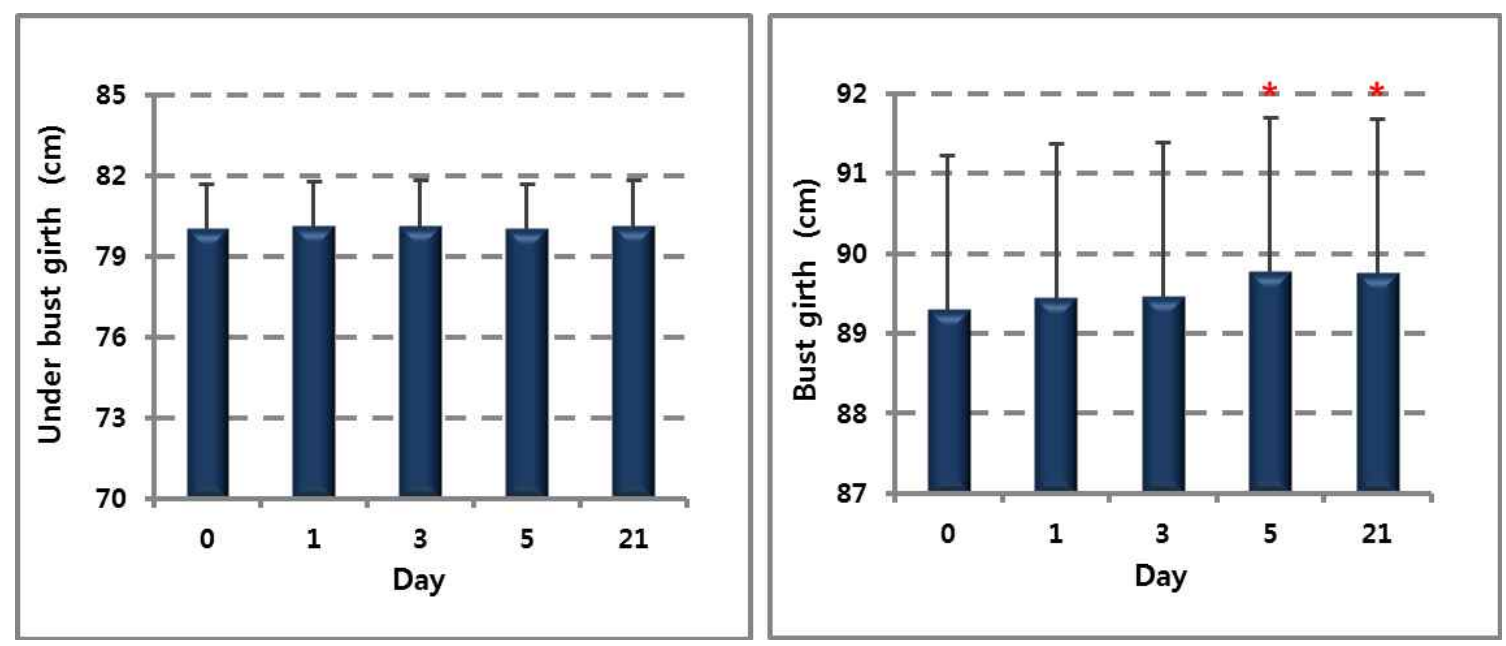

Fig. 5. Changes of under bust and bust girth after using test product. Mean $\pm \mathrm{SEM},{ }^{*} p<0.05$ vs. before treatment.

적에 대한 활성은 다르게 나타났으며, 처리농도에 따라서도 분 화와 지방축적의 저해활성을 나타내는 것을 알 수 있다.

\section{가슴둘레 분석}

지방축적과 세포성장에 효과가 있는 식물체추출물들을 첨 가하여 제조한 천연 팩을 사용하여 밑가슴 둘레를 조사한 결 과 사용전과 변화가 없었으나, 가슴둘레는 사용 5일 후부터 21 일까지 유의적으로 증가하는 결과가 나타났다 $(p<0.05$, Fig. 5). 가슴둘레는 21 일 후까지 지속되어졌으나 가슴볼륨은 11 일 후부터 조금씩 감소하는 것을 확인할 수 있었다(Fig. 7). Chung [5]에 의하면 phytoestrogen 의 복용이 폐경기 전 여성 들의 가슴크기를 증가시키는 결과를 발표했고, 쥐의 실험에서 는 유선의 수가 증가되고, 세포 수가 증가되는 것으로 가슴의
크기를 변화시키는 것을 밝혔다. 식물성 estrogen의 활성은 내인성 estrogen에 비해 약 $1 / 100 ~ 1 / 1,000$ 정도 되지 않으나 체내농도는 100 배 정도 높음으로써 estrogen에 의한 효과를 나타낼 수 있게 된다[9,15]. Q. acutissima, C. lanceolata, P. mirifica, P. bambusoides, S. repens의 추출물을 첨가하여 제조한 천연 팩이 가슴둘레의 크기를 증가시킨 결과를 바탕으로, 다 양한 식물체의 phytoestrogen과 isoflavone 및 기타 화합물들 이 인체에 작용하는 생리적인 기능을 물질의 종류와 양적인 관계의 연구는 흥미를 줄 것이다.

\section{가슴탄력 분석}

여성의 가슴은 노화로 인한 피부의 구조적 변화와 생리적 인 기능감소 그리고 운동, 다이어트, 스트레스 등 주변 환경 


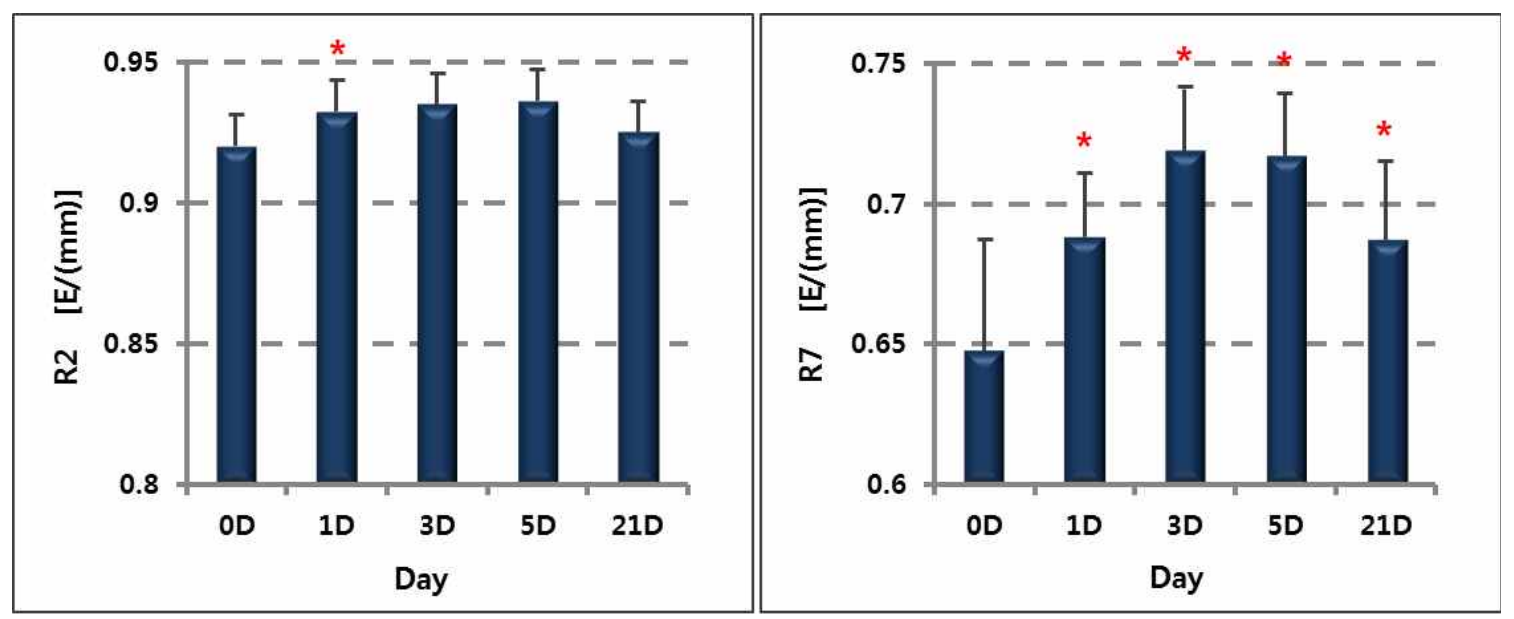

Fig. 6. Changes of bust elasticity after using test product. Mean $\pm \mathrm{SEM},{ }^{*} p<0.05$ vs. before treatment.

에 누적된 외부자극에 의해 가슴이 처지는 현상이 나타나므 로 가슴이 작아 보이게 된다. 하지만 탄력을 증가시키게 되 면 처짐 현상을 보완하여 탄탄한 가슴을 만들 수 있기에 볼 륨이 높아지는 효과를 볼 수 있다. 본 시험은 탄력도 파라미 터를 사용한 것으로 R2 (Ua/Uf : gross elasticity)와 R7 (Ur/Uf : biologic elasticity)은 $1(100 \%)$ 에 가까울수록 피부 탄력도가 높은 것을 의미한다. 총 15 명의 피험자의 가슴 탄 력을 측정한 결과 $\mathrm{R} 2$ 값은 천연 팩 사용 1 일 후 시점에서 가 슴탄력이 개선되었다. 그리고 R7 값은 사용 1일 후부터 탄력 의 변화가 나타났으며, 사용 3 일 후부터 5 일까지 가장 탄력 이 높았고, 사용 후 21 일까지도 사용 전 보다 높은 탄력이 유 지되었다 $(p<0.05$, Fig. 6).

\section{가슴 볼륨 측정}

가슴볼륨 상승효과 조사는 PRIMOS ${ }^{\circledR}$ Body 7.0 를 이용하여 천연 팩 사용 전과 후의 유의성 여부를 가설 평균 차 $5 \%\left({ }^{*} p<0.05\right)$ 로 분석한 결과, 사용 전과 비교했을 때 사용 1 일

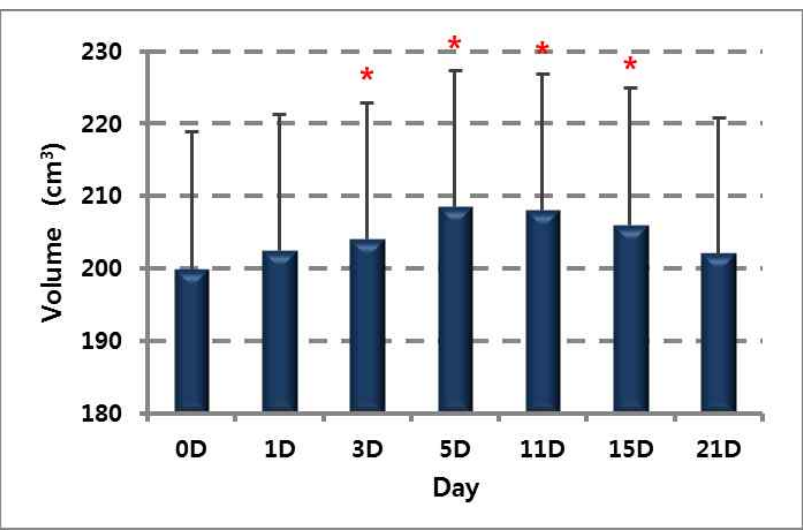

Fig. 7. Changes of bust volume after using test product. Mean \pm SEM, ${ }^{*} \not<0.05$ vs. before treatment.
후부터 변화를 관찰할 수 있었고, 5 일 후에 최대 볼륨 값을 나타냈으며, 11 일 후에 약간의 감소가 있었고, 21 일 후에는 팩 부착 1 일 후와 같은 볼륨 값을 나타냈다(Fig. 7). Phytoestrogen을 첨가한 천연 팩을 5일 연속 부착할 경우 2주 간 이상 부착전보다 높은 볼륨을 유지하는 효과를 보였다. $3 \mathrm{D}$ 이미지 분석 사진에서도 부착 1 일 후부터 변화가 나타났으며, 21 일 후에도 사용전보다 가슴이 확대되어 있는 현상을 확인할 수 있었다(Fig. 8). 홉, 메밀, 회향종자, 호밀, 보리 등으로부터 추출한 phytoestrogen을 복용한 결과, 가슴의 크기가 증가한 다는 결과[5]와 같은 결과가 나타나 phytoestrogen이 여성의 가슴크기를 향상시키는데 효과가 있는 것이 확인 되었으며, 복용하는 것 보다 팩으로 부착하는 것이 효과가 빠른 것으로 나타났다. Phytoestrogen과 isoflavone 류들이 3T3-L1 세포에 대한 지방축적활성과 세포성장 촉진활성이 가슴의 크기를 변 화시키는 것으로 사료되어지나 정확한 작용기전은 더 많은 연구가 필요할 것으로 생각된다.

\section{피부 안전성}

피부 안전성 평가 결과, 피험자 6명(\#01,\#03,\#04,\#05,\#14, $\# 15)$ 이 천연 팩을 사용하였을 때 가벼운 가려움을 호소하였으 나, 그 증상이 미약하여 계속 사용하도록 하였다. 다른 피험자 1명(\#06)은 사용 3 일 후 시점에서 홍반이 관찰 되었으나, 사용 5 일 후 소멸되었고, 그 외의 다른 이상반응은 관찰되지 않아 식물체 추출물들이 피부에 이상증상을 유발하지 않는 것으로 확인되었다(Table 3).

\section{가슴팩 사용 설문평가}

식물추출물을 함유한 천연 팩을 사용한 15 명의 여성 피험자 에게 사용 후 가슴의 크기변화와 만족도 등에 대한 다양한 설문조사를 한 결과는 Table 4 와 같다. 효능에 관한 설문평가 결과는 제품 사용 5 일 후 시점에서 '매끈해짐, 부드러워짐, 촉 


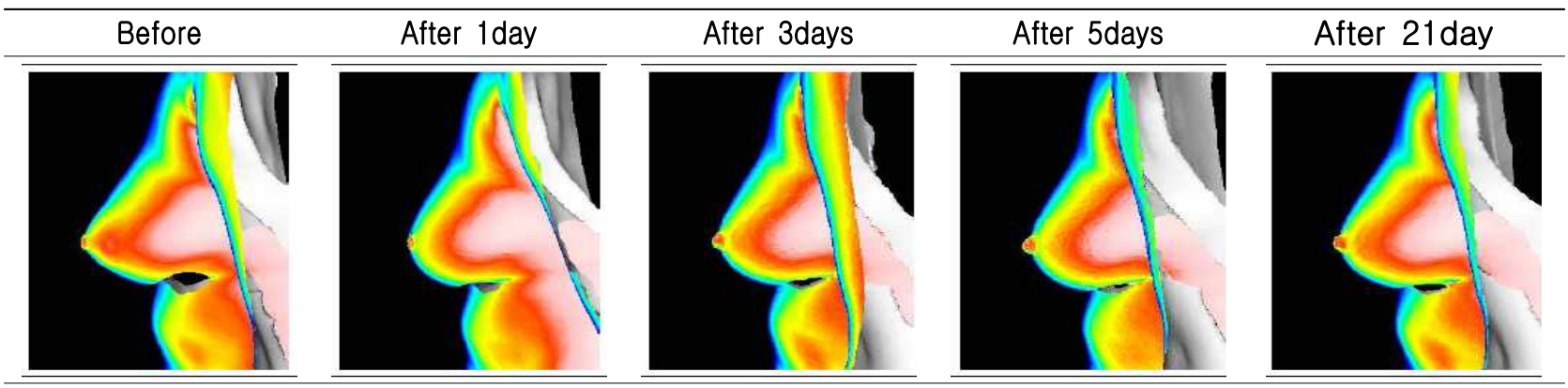

Fig. 8. Changes of bust volume after using test product (Subject No. 5). Mean \pm SEM, ${ }^{*} p<0.05$ vs. before treatment.

Table 3. Skin adverse reactions

\begin{tabular}{|c|c|c|c|c|c|}
\hline Item & & $1 \mathrm{D}$ & $3 \mathrm{D}$ & $5 \mathrm{D}$ & $21 \mathrm{D}$ \\
\hline \multirow{8}{*}{$\begin{array}{l}\text { Subjective } \\
\text { irritation }\end{array}$} & Itching & $1(\# 14)$ & $\begin{array}{c}\text { 6(\#01,\#03,\#04, } \\
\# 05, \# 14, \# 15)\end{array}$ & 2(\#14.\#15) & 0 \\
\hline & Prickling & 0 & 0 & 0 & 0 \\
\hline & Tickling & 0 & 0 & 0 & 0 \\
\hline & Burning & 0 & 0 & 0 & 0 \\
\hline & Sting & 0 & 0 & 0 & 0 \\
\hline & Stiffness & 0 & 0 & 0 & 0 \\
\hline & Tightness & 0 & 0 & 0 & 0 \\
\hline & Etc & 0 & 0 & 0 & 0 \\
\hline \multirow{5}{*}{$\begin{array}{l}\text { Objective } \\
\text { irritation }\end{array}$} & Redness & 0 & 1(\#06) & 0 & 0 \\
\hline & Edema & 0 & 0 & 0 & 0 \\
\hline & Desquamation & 0 & 0 & 0 & 0 \\
\hline & Papule & 0 & 0 & 0 & 0 \\
\hline & Etc & 0 & 0 & 0 & 0 \\
\hline \multicolumn{2}{|c|}{ A number of subjects } & 1 & 7 & 2 & 0 \\
\hline
\end{tabular}

Table 4. Result of self-questionnaires for efficacy $(n=15)$

\begin{tabular}{lcccccc}
\hline \multirow{2}{*}{ Items } & \multicolumn{3}{c}{ 1D } & \multicolumn{3}{c}{ 3D } \\
\cline { 2 - 7 } & $\mathrm{N}^{1}$ & $\%^{2}$ & $\mathrm{~N}^{1}$ & $\%^{2}$ & $\mathrm{~N}^{1}$ & $\%^{2}$ \\
\hline Firmness of bust & 5 & 33.33 & 7 & 46.67 & 10 & 66.67 \\
Softness & 7 & 46.67 & 11 & 73.33 & 13 & 86.67 \\
Bust elasticity & 5 & 33.33 & 8 & 53.33 & 10 & 66.67 \\
Improvement of bust volume & 5 & 33.33 & 8 & 53.33 & 10 & 66.67 \\
How feel wearing bra & 4 & 26.67 & 6 & 40.00 & 10 & 66.67 \\
Bust lifting & 4 & 26.67 & 5 & 33.33 & 10 & 66.67 \\
Improvement of bust line & 1 & 6.67 & 8 & 53.33 & 8 & 53.33 \\
Moisture & 9 & 60.00 & 13 & 86.67 & 14 & 93.33 \\
Slip & 9 & 60.00 & 12 & 80.00 & 12 & 80.00 \\
Satisfaction & 4 & 26.67 & 8 & 53.33 & 12 & 80.00 \\
\hline
\end{tabular}

${ }^{1} \mathrm{~N}$ (Frequency): Number of positive answers

${ }^{2} \%$ (Percentage) $=$ Frequency $(\mathrm{N}) /$ Number of total subjects $(15) \times 100$

촉함, 만족도' 항목에서는 $80 \%$ 이상 긍정적인 답을 했으며, '탄 탄해짐, 가슴탄력, 볼륨, 속옷 착용 시 변화, 리프팅' 항목에서 는 $65 \%$ 이상이 긍정적으로 응답하였다(Table 4). 또한, 사용 후 2주가 경과한 21일째에 ‘리프팅 유지, 탄탄함 유지, 탄력 유지,
만족도' 항목은 피험자의 $50 \%$ 이상이 긍정적인 응답을 하였으 며(Table 5), 이는 Q. acutissima, C. lanceolata, P. mirifica, $P$. bambusoides, S. repens의 추출물을 함유한 천연 팩을 사용할 경우 탄력이 유지되고, 가슴의 크기가 개선되어지는 효과가 
Table 5. Result of self-questionnaires for efficacy $(n=15)$

\begin{tabular}{lcc}
\hline \multirow{2}{*}{ Items } & \multicolumn{2}{c}{$21 \mathrm{D}$} \\
\cline { 2 - 3 } & $\mathrm{N}^{1}$ & $\%^{2}$ \\
\hline Continuous to keep bust firmness & 8 & 53.33 \\
Continuous to keep bust elasticity & 9 & 60.00 \\
Continuous to keep bust volume & 7 & 46.67 \\
Continuous to keep lifting effect & 8 & 53.33 \\
Satisfaction & 9 & 60.00 \\
\hline
\end{tabular}

${ }^{1} \mathrm{~N}$ (Frequency): Number of positive answers

${ }^{2} \%$ (Percentage) $=$ Frequency $(\mathrm{N}) /$ Number of total subjects $(15) \times 100$

Table 6. Result of self-questionnaires for usability $(n=15)$

\begin{tabular}{lcc}
\hline Items & $\begin{array}{c}\text { Frequency } \\
\left(\mathrm{N}^{1}\right)\end{array}$ & $\begin{array}{c}\text { Percentage } \\
\left(\% \%^{2}\right)\end{array}$ \\
\hline Usability & 14 & 93.33 \\
Fragrance & 11 & 73.33 \\
Absorption & 12 & 80.00 \\
Convenient to use & 7 & 46.67 \\
Satisfaction & 11 & 73.33 \\
Purchase intention & 9 & 60.00 \\
Recommendation intention & 10 & 66.67 \\
\hline
\end{tabular}

${ }^{1} \mathrm{~N}$ (Frequency): Number of positive answers

${ }^{2} \%$ (Percentage)=Frequency (N)/Number of total subjects $(15) \times 100$

21일 이상 유지되는 것을 알 수 있었다. 크림형태의 제품은 마사지방법으로 시간을 두고 문질러야하며, 마르기 전에는 옷 을 착용하는 것이 어렵고, 손을 씻어야하는 불편함이 있다. 그러나 팩은 가슴에 부착하는 방식이므로 간편하며, 활동에도 불편함이 없고 지속적으로 사용할 수 있어 효과를 높일 수 있는 장점이 있다. 이러한 편리성으로 인하여 사용에 따른 설 문평가 결과, 향, 만족도 및 흡수력 항목에서는 피험자의 $70 \%$ 이상 긍정적으로 평가하였으며, 사용 느낌조사에서는 $90 \%$ 이 상이 긍정적으로 평가하였다(Table 6). 식물체추출물을 첨가 한 천연 팩은 가슴의 크기변화와 사용의 편리성 그리고 사용 후 만족감에 대한 긍정적인 평가는 관련 제품개발에 기초자료 로서 활용이 가능할 것이다.

\section{감사의 글}

이 논문은 부산대학교 자유 과제 학술연구비(2년)에 의하여 연구되었음.

\section{References}

1. Cain, J. C. 1960. Miroestrol-estrogen from the plant, Pueraria mirifica. Nature 188, 774-777.

2. Chansakaow, S., Ishikawa, T., Seki, K., Okada, M., Higuchi,
Y., Kudo, M. and Chaichantipyuth, C. 2000. Isoflavonoids from Pueraria mirifica and their estrogenic activity. Plant Med 66, 572-575.

3. Cherdshewasart, W., Sriwatcharakul, S. and Malaivijitnond, S. 2008. Variance of estrogenic activity of the phytoestrogen-rich plant. Maturitas 61, 350-357.

4. Christian, N. 2008. Woman's bodies, woman's wisdom: The complete guide to woman's health and wellbeing. pp. 265-288, Piatkus Books Ltd.

5. Chung, J. H. 2003. Breast augmentation by the effect of phytoestrogen. New Medical J. 46, 65-69.

6. Codner, M. A., Cohen, A. T. and Hester, T. R. 2001. Complications in breast augmentation: prevention and correction. Clin. Plast Surq. 28, 587-595.

7. Gallager, H. S., Leis, H. P., Snyderman, R. K. and Urban, J. A., eds. 1978. The Breast. pp. 28-53 St. Louis, C. V. Mosby Co.

8. Ganry, O. 2002. Phytoestrogen and breast cancer prevention. Eur. J. Cancer Prev. 11, 519-522.

9. Garrett, S. D., Lee, H. A., Friar, P. M. and Morgan, M. R. 1999. Validation of a novel estrogen receptor based microtitration plate assay for the determination of phytoestrogens in soy-based foods. J. Agric. Food Chem 47, 4106-4111.

10. Kim, B., Jung, S. W., Lee, J. D., Ryoo, H. C. and Cherdshewasart, W. 2004. Clinical study of ream containing Pueraria mirifia for skin elasticity. J. Soc. Cosmet. Scientists Korea 30, 385-388.

11. Kim, S. H. and Kim, S. K. 2009. A study on the behavior of cosmetic surgery of working women in their 20s-30s according to the degree of importance of outward appearance. J. Korea Soc. Beauty Art 10, 5-15.

12. Kim, Y. R. 2008. Effects of Sasa borealis leaves extracts on the differentiation of adipocytes and lipid metabolism. M.S Thesis, Chonnam national university, Gwangju, Korea.

13. Lamartiniere, C. A., Zhang, J. X. and Cotroneo, M. S. 1998. Genistein studies in rats: potential for breast cancer prevention and reproductive and developmental toxicity. $A m$ J. Clin. Nutr. 68, 1400S-1405S.

14. Lee, S. D. 2004. Complications and Reasons for Dissatisfaction in Augmentation Mammoplasty. J. Breast Cancer 7, 121-125.

15. Messina, M. J., Persky, V. K., Setchell, D. and Barnes, S. 1994. Soy intake and cancer risk a review of the in vitro and in vivo data. Nutr. Cancer 21, 113-131.

16. Park, H. M. 2007. The efficacy of phytoestrogen in postmenopausal women. Korean J. Obstetrics and Gynecology 50, 389-415.

17. Patisaul, H. B. 2005. Phytoestrogen action in the adult and developing brain. J. Neuroendocrinology 17, 57-64.

18. Pisha, E. and Pezzuto, J. M. 1997. Cell-based assay for the determination of estrogenic and anti-estrogenic activities. Methods in Cell Science 19, 37-43.

19. Rudd, N. A. and Lennon, S. J. 2001. Body image: linking aesthetics and social psychological of appearance. CTRJ. 19, 120-133.

20. Ruggiero, R. J. and Likis, F. E. 2002. Estrogen: physiology, 
pharmacology, and formulation for replacement therapy. $J$. Midwifery Womens Health 47, 130-138.

21. Schmidt, J. B., Binder, M., Demschik, G., Bieglmayer, C. and Reiner, A. 1996. Treatment of skin aging with topical estrogens. Int. J. Dermatol. 35, 669-674.

22. Tempfer, C. B., Bentz, E. K. and Leodolter, S. 2007. Phytoestrogens in clinical practice: a review of the literature. Fertil. Steril. 87, 1243-249.

23. Wang, W., Tanaka, Y., Han, Z. and Higuchi, C. 1995. Proliferative response of mammary glandular tissue to formononetin. Nutr. Cancer 23, 131-140.
24. Wichal, C. 2004. Extracts derived from Pueraria mirifica, Butea superba and/or Mucuna colllettii and extraction thereof. US 6673371.

25. Zhang, Y. and Ding, X. L. 1996. Studies on antioxidative fraction in bamboo leaves and its capacity to scavenge activity oxygen radicals. J. Bamboo Res. 15, 17-24.

26. Zhang, Y, Shen, J. F., Yu, Z. Y., Lou, B. Y. and Lou, D. D. 2004. Primary studies on bamboo leaf flavonoids used as anti-aging factor for skin protection. Chem Ind Forest Prod 24, $95-100$

\section{초록 : 식물추출물 팩의 여성가슴 탄력증진과 크기증대에 관한 연구}

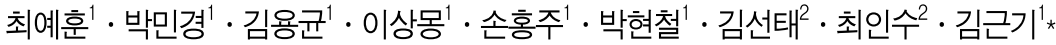

( ${ }^{1}$ 부산대학교 생명환경화학과, ${ }^{2}$ 부산대학교 식물생명과학과)

본 연구는 콩과식물과 허브식물 및 국내 자생식물체들로부터 estrogen 생성과 대사에 활성을 나타내는 물질을 발굴하기 위하여, 12 종의 식물체로부터 식물 유래의 isoflavone류를 포함한 2차대사산물을 용매로 추출하여 지방 세포의 지방합성과 축적에 활성을 조사하였다. 활성을 보이는 Q. acutissima, C. lanceolata, P. mirifica, P. bambusoides 및 S. repens 5 종의 식물체 용매추출물을 전체중량의 $3 \%$ 되게 첨가하여 천연 팩을 제조하였으며 임상실험 을 통하여 가슴의 탄력과 크기변화에 미치는 영향을 조사하였다. C. lanceolata 추출물을 $25 \mu \mathrm{g} / \mathrm{ml}$ 농도로 처리한 곳에서 3T3-L1의 세포성장을 control과 비교했을 때 $130 \%$ 이상 증가시켰으며, 지방의 축적은 S. repens $\mathrm{H}_{2} \mathrm{O}$ 추출 물을 처리한 곳에서 $190 \%$ 정도 지방축적량이 많았으며, C. lanceolata와 P. bambusoides EtOH 추출물을 처리한 곳 에서도 각각 $145 \%$ 와 $154 \%$ 활성이 높게 나타났다. 지방합성을 촉진하는 식물체추출물들을 첨가하여 천연 팩을 제조하였으며, 제조한 팩으로 더마프로에 가슴크기 변화와 탄력에 미치는 영향 등의 임상실험을 의뢰하였다. 임 상 실험 결과, 가슴둘레, 탄력, 볼륨이 모두 유의적으로 향상되는 것을 확인할 수 있었고. 효능에 관한 설문평가 결과, 사용효과 항목에서 $80 \%$ 이상의 긍정적으로 답하였으며, 사용 후 2 주간 효과에 대해 $65 \%$ 이상이 긍정적인 응답을 하였다. 사용성 설문평가 결과 또한 피험자의 $90 \%$ 이상이 긍정적으로 평가하였다. 피부 안전성 평가에서 는 피험자 6 명이 사용 중 가려움을 호소하였으나, 그 증상이 미약하여 사용에는 문제가 없었으며, 1 명은 사용 3 일 후 홍반이 관찰되었으나 5일 후 소멸되었고, 그 외의 다른 이상반응은 관찰되지 않아 인체에 대한 부작용의 문제는 없었다. 이상의 연구 결과, Q. acutissima, C. lanceolata, P. mirifica, P. bambusoides 및 S. repens의 추출물을 혼합하여 첨가한 겔타입의 팩 제조물은 여성의 가슴크기 향상과 탄력유지에 유효하다는 사실을 세포수준의 실험 과 임상실험에서 그 효과를 확인 할 수 있었다. 